\title{
Chlorine Concentration and the Inoculation of Tomato Fruit in Packinghouse Dump Tanks
}

J. A. Bartz, Plant Pathology Department, University of Florida, Gainesville 32611-0680; C. G. Eayre, USDAARS, Water Management Research Laboratory; Parlier, CA; M. J. Mahovic and D. E. Concelmo, Plant Pathology Department, University of Florida; and J. K. Brecht and S. A. Sargent, Horticultural Sciences Department, University of Florida

\begin{abstract}
Bartz, J. A., Eayre, C. G., Mahovic, M. J., Concelmo, D. E., Brecht, J. K., and Sargent, S. A. 2001. Chlorine concentration and the inoculation of tomato fruit in packinghouse dump tanks. Plant Dis. 85:885-889.

Chlorine concentrations ( $\mathrm{pH} 6$ to 7 and 22 to $27^{\circ} \mathrm{C}$ ) that killed arthrospores (spores) of Geotrichum candidum or sporangioles (spores) of Rhizopus stolonifer, causal agents of sour rot and Rhizopus rot, respectively, in moving water within 30 to $45 \mathrm{~s}$ did not prevent these pathogens from inoculating wounded tomatoes (Lycopersicon esculentum) in a water flume containing chlorine and spores. Free chlorine concentrations of 20 or $25 \mathrm{mg} / \mathrm{liter}$ were lethal to spores of $G$. candidum within $30 \mathrm{~s}$ in most in vitro tests, whereas spores of $R$. stolonifer were slightly less sensitive. Wounded tomatoes placed in a flume with free chlorine at $30 \mathrm{mg} / \mathrm{liter}$ and then exposed to spores for 1 min developed about $50 \%$ less decay incidence during storage at $24^{\circ} \mathrm{C}$ for 6 days than did fruit exposed to spores and water alone. In the absence of chlorine, incidence averaged 57\% (range, 15 to $95 \%$ ) for $R$. stolonifer and 38\% (range, 17 to 58\%) for $G$. candidum. Sporadic sour rot lesions were observed among fruit that had been treated with free chlorine at $75 \mathrm{mg} /$ liter, whereas chlorine at up to $180 \mathrm{mg} /$ liter failed to completely protect fruit from Rhizopus rot. A water-soluble dye rapidly penetrated wounds on tomato fruit. The dye framed the outlines of cells at the wound surface and appeared to penetrate into a few intercellular spaces. Application of $1 \%$ sodium hypochlorite decolorized the dye on the wound surface, whereas deposits located below the wound surface remained blue. Thus, spores suspended in moving water can escape the action of chlorine if carried into intercellular spaces by diffusion or by capillary movement of cell sap and water.
\end{abstract}

Additional keywords: packinghouse sanitation, postharvest decay, water chlorination

Recommendations for chlorination of water systems in tomato packinghouses are largely supported by anecdotal reports. Suggested free chlorine concentrations (sum of hypochlorous acid $[\mathrm{HOCl}]$ and hypochlorite ion $\left[\mathrm{OCl}^{-}\right]$) for dump tanks and flume systems are 70 to 100 (13) or 100 to $150 \mathrm{mg} / \mathrm{liter}(11,16)$. Spray washes that clean tomatoes exiting a dump tankflume system may contain free chlorine at up to $350 \mathrm{mg} / \mathrm{liter}$ (13). These recommendations, however, are not based on research data. A chlorine overdose was included such that "sufficient" free chlorine will be present at all times, although sufficient was not defined $(3,11,13,16)$.

Free chlorine concentrations in packinghouse dump tank and flume systems decrease as chlorine demand (sum of all ma-

Corresponding author: J. A. Bartz

Email: jabar@gnv.ifas.ufl.edu

Florida Agricultural Experiment Station Journal Series No. R-07804.

Accepted for publication 26 April 2001.

Publication no. D-2001-0618-03R

(C) 2001 The American Phytopathological Society terials that react with $\mathrm{HOCl}$ or $\mathrm{OCl}^{-}$) enters the system. Most of the products of the reaction of chlorine with chlorine demand have little antimicrobial activity $(3,6,8,19)$. Microbes are killed primarily by $\mathrm{HOCl}$. The $\mathrm{OCl}^{-}$component, although a strong oxidant, is between 20 to 300 times less toxic (19). Solution $\mathrm{pH}$ and, to a lesser extent, temperature control the ratio of acid to ion. At $\mathrm{pH} \mathrm{7.5,} \mathrm{the} \mathrm{ratio} \mathrm{is} \mathrm{approxi-}$ mately 50:50. At pH 6.0, 95 to $97 \%$ of the free chlorine in chlorinated water is $\mathrm{HOCl}$. The product used to replenish the chlorine lost to demand reactions affects the solution $\mathrm{pH}(8,19)$. Thus, both free chlorine concentration and solution $\mathrm{pH}$ must be adjusted periodically during a workday to keep the water system free of potentially hazardous populations of microorganisms.

Equipment is available for maintaining constant levels of free chlorine and solution $\mathrm{pH}$ in packinghouse water systems (14). The oxidation-reduction potential (ORP) and $\mathrm{pH}$ can be maintained automatically $(6,14,19)$. The ORP correlates well with free chlorine concentrations that kill cells of Escherichia coli and other microbes (6) as well as arthrospores (spores) of Geotrichum candidum or cells of Erwinia carotovora subsp. carotovora
(14). The rapid response of on-line ORP systems to changes in free chlorine concentration and solution $\mathrm{pH}$ eliminates the need for chlorine overdoses.

The minimum free chlorine concentration required to prevent the inoculation of fruits and vegetables in packinghouse water systems is not clear. Free chlorine at less than $1 \mathrm{mg} / \mathrm{liter}$ as $\mathrm{HOCl}$ kills nonspore-forming bacteria within seconds $(6,8,19)$, whereas fungal conidia survive exposure to $\geq 20 \mathrm{mg} / \mathrm{liter}$ for $2 \mathrm{~min}$ or longer, depending on the species. In tests by Robbs et al. (14), a 2-min exposure to chlorine at $25 \mathrm{mg} /$ liter at $25^{\circ} \mathrm{C}$ and $\mathrm{pH} 6$ or 7 produced a $6.0 \log _{10}$ kill of spores of $G$. candidum. Ferreira et al. (9) found that free chlorine at more than $80 \mathrm{mg} / \mathrm{liter}$ was required for a 5.3 to $5.7 \log _{10}$ kill for sporangioles (spores) of Rhizopus stolonifer during a 2-min treatment at $\mathrm{pH} 7.0$ and $5^{\circ} \mathrm{C}$.

Pathogen sensitivity to chlorine in vitro does not correlate well with that found in tests with fruit. In tests of Brown and Wardowski (5), spores of Penicillium digitatum that had been treated with chlorine at 100 $\mathrm{mg} / \mathrm{liter}(\mathrm{pH} 7.0)$ for $10 \mathrm{~s}$ and then spread over potato dextrose agar (PDA) did not germinate within a 24 -h incubation period. G. candidum was equally sensitive. However, $P$. digitatum was isolated from naturally infested but healthy oranges that had been treated with a 15-s spray containing free chlorine at $200 \mathrm{mg} / \mathrm{liter}(\mathrm{pH} 6.8$ to 7.0 ), and $G$. candidum was isolated from fruit similarly treated with $1,000 \mathrm{mg} / \mathrm{liter}$. Spotts and Peters (18) reported a complete inhibition of germination when spores of Mucor piriformis were treated with chlorine at $50 \mathrm{mg} /$ liter for $30 \mathrm{~s}$ and then incubated for $24 \mathrm{~h}$ on PDA. However, when treated spores were placed in wounds on pears, $13 \%$ of the fruit developed lesions within 7 days at $18^{\circ} \mathrm{C}$. In evaluations of commercially packed tomato fruit that had been stored for 2 weeks, Bender et al. (4) found no difference in decay incidence among fruit that had passed through a packinghouse dump tank or flume system maintained at $\mathrm{pH} 7.0$ and $40^{\circ} \mathrm{C}$ with chlorine at 50 versus 80 or 50 versus 100 $\mathrm{mg} / \mathrm{liter}$ in two separate tests.

Most microbe inactivation models are based on the disinfection of potable water where free chlorine concentrations are maintained for several minutes or longer 
$(6,19)$. In packinghouse water systems, however, chlorine must prevent movement of pathogens from sources to potential infection courts, a process that may occur within a second or two. The surfaces of freshly harvested fruits and vegetables have populations of various microorganisms (10). Senter et al. (15) recovered $\log _{10}$ 6.2 to $7.6 \mathrm{CFU}$ of bacteria per tomato fruit entering two packinghouses in South Carolina. In samples from three separate packinghouses in Florida, Bartz (unpublished data) isolated $\log _{10} 6.5$ to $7.7 \mathrm{CFU}$ per fruit. Many of the microbes on tomato surfaces become suspended in water as the fruit splash into the receiving tank, float down the flume, and roll through a washer (10). Additionally, an occasional decayed fruit may enter the system (M. J. Mahovic and S. A. Sargent, unpublished data). In this article, we report tests on the effect of chlorine concentrations on the dispersal of pathogen spores through a simulated water flume to wounds on tomato fruit. In particular, we explored whether free chlorine would provide a chemical barrier on wounds that would prevent the entrance of viable decay pathogens.

\section{MATERIALS AND METHODS}

Spore suspensions and tomato fruit. Aqueous suspensions of spores of G. candidum and $R$. stolonifer were produced from 7- to 14-day-old PDA cultures (14). Suspensions of $R$. stolonifer were filtered through several layers of cheesecloth. Numbers of spores in stock suspensions of $R$. stolonifer were counted in a hemacytometer, whereas numbers of $G$. candidum were calculated from a regression of spore concentration over optical density measured with a spectrophotometer (Spectronic 20; Bausch and Lomb, Inc., Rochester, NY; 14).

Tomato fruit were obtained from packinghouses on the west coast of Florida, research plots located in north-central Florida, or a tomato distribution firm. Tomatoes were selected for an absence of wounds or blemishes and a uniform mix of ripeness but were not otherwise treated before use.

Scale model flume and chlorine feed system. The edge of a 35-by-106-cm plexiglass sheet was glued to the bottom of a rectangular fiberglass tank that was 43 $\mathrm{cm}$ high by $138 \mathrm{~cm}$ long by $48 \mathrm{~cm}$ wide. The resulting partition was $18 \mathrm{~cm}$ from the side of the tank and equidistant from the tank ends, forming a compartment with a 16-cm opening at each end. A submersible utility pump $($ model $2 \mathrm{E}-\mathrm{N}$, performance $=$ 18.9 liters $/ \mathrm{min}$ at $30.5 \mathrm{~cm}$ from the outlet; Little Giant Pump Company, Oklahoma City, OK) placed inside the compartment forced water through the compartment and around the tank's perimeter, forming a flume. ORP and $\mathrm{pH}$ electrodes (Strantrol Inc., Bradley, IL) were fastened near the compartment entrance. Tubes for the auto- matic addition of diluted laundry bleach $(0.5 \%$ sodium hypochlorite) and hydrochloric acid $(1 \mathrm{M})$ to the water were fastened by the compartment exit. These "feed" tubes were connected by peristaltic pumps to reservoirs of bleach or $\mathrm{HCl}$. The tank was filled to a depth of $23 \mathrm{~cm}$, which required 150 liters of city tap water. Na$\mathrm{HCO}_{3}$ was added to increase water alkalinity from approximately 60 to $130 \mathrm{mg} / \mathrm{liter}$. The ORP and $\mathrm{pH}$ detection-feed pump systems maintained a stable ORP and $\mathrm{pH}$ during the tests. The final water temperature was $24^{\circ} \mathrm{C}$.

A small flume was created by the placement of a "fountain pump" (performance = 1 liter/min at $30.5 \mathrm{~cm}$ from outlet; Beckett Corp., Irving, TX) on its side at the bottom of a 14-liter plastic pail containing 4 liters of tap water at $27^{\circ} \mathrm{C}$. Phosphate buffer $(0.01 \mathrm{M})$ was added to maintain $\mathrm{pH}$ 7.0.

Water movement in the model flumes. Samples of an aqueous solution of water blue (acid blue 22) or methylene blue dye (The Coleman \& Bell Co., Norwood, OH) at approximately $0.1 \mathrm{mg} / \mathrm{ml}$ were added to the water at the pump intake in both the 4and 150-liter flumes and the subsequent dispersal of dye monitored. A 10-ml sample of an aqueous spore suspension of $G$. candidum was similarly added to the 150liter tank. Samples $(0.5 \mathrm{ml})$ were removed at the compartment entrance (end of one complete movement around the tank) at 10-s intervals and spread over lactic acid PDA (approximately one drop of an aqueous solution of $50 \%$ lactic acid per $20 \mathrm{ml}$ of agar [APDA]) in 100-by-15-mm petri dishes. The agar plates were incubated for $48 \mathrm{~h}$ at $24^{\circ} \mathrm{C}$ and examined for development of colonies of $G$. candidum.

Efficacy of chlorinated water against G. candidum or R. stolonifer. Water in the 150-liter flume was chlorinated to a concentration of $20 \mathrm{mg} / \mathrm{liter}$. A $10-\mathrm{ml}$ suspension of spores of G. candidum or R. stolonifer was added at the pump intake. At 15-s intervals thereafter, samples were removed from the flume at the entrance to the compartment and immediately spread over APDA. The chlorine concentration was increased to $25 \mathrm{mg} / \mathrm{liter}$ as suggested by Robbs et al. (14) for a $5-\log _{10}$-spore reduction for $G$. candidum within $2 \mathrm{~min}$, and the test was repeated. At each concentration, tests were repeated at least twice. In a second series of tests with G. candidum, spores were added to water with a chlorine concentration of $20 \mathrm{mg} / \mathrm{liter}$ in $0.01 \mathrm{M}$ phosphate buffer ( $\mathrm{pH} \mathrm{6.0)}$ at $22^{\circ} \mathrm{C}$ that was contained in a beaker and stirred continuously. At 16 15-s intervals, 10- $\mu \mathrm{l}$ samples were removed and spotted on APDA amended with $0.2 \%$ thiosulfate. The plates were incubated up to $72 \mathrm{~h}$ at $20^{\circ} \mathrm{C}$. The density of the growth on each spot after 72 $\mathrm{h}$ of incubation was compared against a template prepared from a serial 10 -fold dilution of a known concentration of spores. There were three separate tests with three samples from each beaker at each time interval.

Efficacy of chlorinated water for preventing inoculation of wounded tomato fruit in a flume. In tests with the 150-liter flume, fruit at 20 to $24^{\circ} \mathrm{C}$ were wounded four times to a depth of $6 \mathrm{~mm}$ with a pointed probe that tapered from $1.5 \mathrm{~mm}$ at its tip to $3 \mathrm{~mm}$ in diameter at its greatest width. The wounded fruit were added to water containing various chlorine concentrations and then a 10-ml sample of spore suspension was added at the pump intake. Final spore concentrations ranged from $\log _{10} 2.4$ to $3.5 / \mathrm{ml}$ depending on the test. After $1 \mathrm{~min}$, the tomatoes were removed and incubated under high humidity at $24^{\circ} \mathrm{C}$ for 6 days. At daily observations, diseased fruit were removed to prevent fruit-to-fruit spread of decay. The sequence of treatments began with the water alone treatment, which was followed by water plus inoculum and then the lowest chlorine level plus inoculum. At each chlorine level, four separate samples of 15 fruit were added to the water followed by fresh inoculum. There was a 5-min equilibration period between each treatment replication as well as between each treatment. During equilibration periods, the chlorine concentration was measured with the diethyl- $p$ phenylene diamine (DPD) test as described (14) and the system $\mathrm{pH}$ compared against measurements with a $\mathrm{pH}$ meter (Orion Research Inc.; Beverly, MA). There were five separate tests each with $G$. candidum and $R$. stolonifer.

In tests with the 4-liter flume, five fruit at $22^{\circ} \mathrm{C}$, each with 10 probe punctures, were placed in the chlorinated water $\left(27^{\circ} \mathrm{C}, \mathrm{pH} 7.0\right)$. Inoculum ( $\log _{10} 5.0$ conidia of $R$. stolonifer $/ \mathrm{ml}$ ) was injected via pipette near the pump intake and fruit were removed after $2 \mathrm{~min}$. In a second test, three fruit, each with 20 punctures, were treated similarly. After treatment, individual fruit were placed in isolated positions on a Styrofoam depression tray and incubated at $20^{\circ} \mathrm{C}$ for 4 days. The tray was lined with wet paper towels and enclosed in a plastic bag to maintain high relative humidity.

Statistical analysis. In the 150-liter flume tests, fruit samples treated in succession were considered replicates because the volume of water required to fill the tank precluded randomization of individual treatments. Disease incidence or spore population recovered after treatment were plotted against chlorine concentration by SigmaPlot for Windows 5.0 (SPSS, Inc., Richmond, CA). Error bars represent the standard error of the mean.

\section{RESULTS}

Water movement in the model flumes. Dye solutions entered the pump intake and exited the outlet as a plume. None of the dye dispersed directly from the point of addition. In the 150-liter rectangular flume, the dye plume dissipated into uniform 
color within $10 \mathrm{~s}$. In the 4-liter circular flume, the dye plume became uniformly dispersed within $5 \mathrm{~s}$. A few $(<10)$ colonies of $G$. candidum developed on APDA that had been spread with water samples removed from the compartment entrance in the 150-liter flume at $10 \mathrm{~s}$ after spore addition to the pump intake (data not shown). Water samples removed at 20 to $240 \mathrm{~s}$ produced more numerous colonies on APDA and the number was relatively uniform.

Efficacy of moving chlorinated water against $\boldsymbol{G}$. candidum or $R$. stolonifer. In all in vitro tests with both fungi, visible fungal growth was observed within $24 \mathrm{~h}$ after untreated spores had been placed on APDA. In contrast, visible growth did not appear until 48 or $72 \mathrm{~h}$ after the chlorinetreated spores were spread plated. In tests with the 150-liter flume, samples with free chlorine at $20 \mathrm{mg} /$ liter at $\mathrm{pH} 7.0$ and $\log _{10}$ 2.7 to 3.0 spores of $G$. candidum per milliliter removed after 15 and $30 \mathrm{~s}$ produced colonies on APDA in two of three tests (data not shown). In the third test, the 30-s sample did not produce colonies, whereas the 15-s sample did. Colonies did not develop from samples removed at $\geq 45 \mathrm{~s}$ in any test. When the chlorine concentration was increased to $25 \mathrm{mg} / \mathrm{liter}$, the results were similar, except that fewer viable spores were recovered after $15 \mathrm{~s}$. In the beaker tests, samples of $G$. candidum removed after $\geq 45 \mathrm{~s}$ exposure to chlorine concentrations of $20 \mathrm{mg} /$ liter did not produce colonies on APDA amended with thiosulfate, whereas those removed after $15 \mathrm{~s}$ did (data not shown). In one of three replicates of one of three separate tests, sparse growth (equivalent to a $4 \log _{10}$ reduction) was detected among sites spotted with spores treated for $30 \mathrm{~s}$. The average growth from the 15-s samples was equivalent to a $3 \log _{10}$ reduction.

In tests with the 150-liter flume, chlorine at $20 \mathrm{mg} / \mathrm{liter}$, and $R$. stolonifer at $\log _{10}$ 2.6-3.0 spores/ml, viable spores were

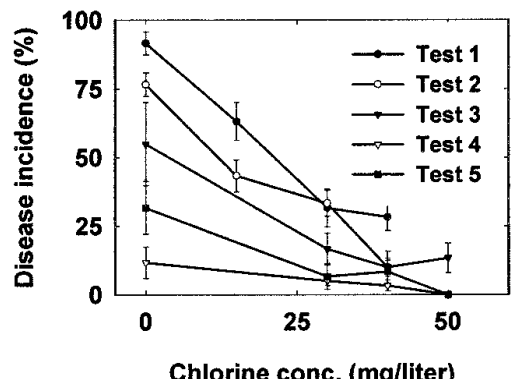

Fig. 1. Disease incidence among tomato fruit that had been wounded four times $(6 \mathrm{~mm}$ deep, $3 \mathrm{~mm}$ wide tapering to $1.5 \mathrm{~mm}$ ) and exposed to chlorinated water and spores of Rhizopus stolonifer $\left(\log _{10} 2.6\right.$ to $\left.3.0 / \mathrm{ml}\right)$ for $1 \mathrm{~min}$ in a 150 liter scale model flume and then stored for 6 days at $24^{\circ} \mathrm{C}$ in five separate tests. Error bars are the standard error of the mean of four separate 15 -fruit samples. recovered after 75 but not $90 \mathrm{~s}$ in two separate tests. When the chlorine concentration was increased to $25 \mathrm{mg} / \mathrm{liter}$, viable spores were recovered after 30 but not $45 \mathrm{~s}$ in two separate tests.

Efficacy of chlorinated water for preventing inoculation of wounded tomato fruit in a flume. Decay incidence usually exceeded $50 \%$ among control fruit that were exposed to inoculum alone. Disease incidence among wounded fruit suspended in clean tap water ranged from 0 to $11.7 \%$ depending on the fruit lot. This "natural" incidence was highest among tomatoes harvested during the summer.

In five separate tests with wounded tomatoes in the 150-liter flume, decay incidence among control fruit exposed to spores of $R$. stolonifer varied from $95 \%$ after 4 days of storage to $15 \%$ after 6 days. Spore concentrations were $\log _{10} 3.4 / \mathrm{ml}$ for the test leading to the highest decay incidence and $\log _{10} 2.3 / \mathrm{ml}$ for the lowest. Disease incidence was reduced by greater that $50 \%$ of the control value by the addition of chlorine at $30 \mathrm{mg} / \mathrm{liter}$, but was not completely prevented by $40 \mathrm{mg} / \mathrm{liter}$ (Fig. 1). In the third test, Rhizopus rot developed among fruit treated in a chlorine concentration of $50 \mathrm{mg} / \mathrm{liter}$.

In tests with the 4-liter flume, a 2-min exposure period, and $\log _{10} 5.0$ spores $/ \mathrm{ml}$, Rhizopus rot developed among a few fruit treated with chlorine at $180 \mathrm{mg} / \mathrm{liter}$, whereas $100 \%$ developed on wounds of fruit exposed to spores alone (inoculated controls; Fig. 2). By contrast, the incidence among fruit treated with free chlorine at 30 $\mathrm{mg} / \mathrm{liter}$ was greater than $60 \%$.

In five separate tests with $G$. candidum and the 150-liter flume, disease incidence among the inoculated control fruit ranged from 17 to $58 \%$ (Fig. 3). In four of the five tests, chlorine at $30 \mathrm{mg} / \mathrm{liter}$ reduced disease incidence to less than half of the incidence found among the control fruit. In-

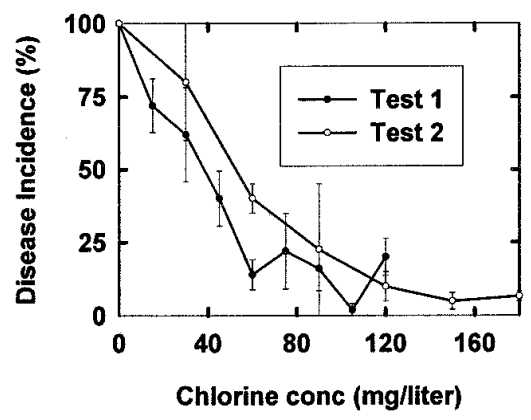

Fig. 2. Disease incidence (percentage of wounds with symptoms) after 4 days of storage at $20^{\circ} \mathrm{C}$ of fruit that had been wounded $(6 \mathrm{~mm}$ deep, $3 \mathrm{~mm}$ wide tapering to $1.5 \mathrm{~mm}$ ) and exposed to chlorinated water and spores of Rhizopus stolonifer $\left(\log _{10} 5.0 / \mathrm{ml}\right)$ for $2 \mathrm{~min}$ in a 4-liter scale model flume in two separate tests. Error bars are the standard error of the mean of five fruit with 10 wounds or three fruit with 20 wounds each in test one or two, respectively. consistent levels of disease developed among fruit treated with chlorine at 40 to $75 \mathrm{mg} / \mathrm{liter}$ but, in all tests, less than $10 \%$ decay was found among the 50-mg/liter treatments.

\section{DISCUSSION}

Concentrations of free chlorine that were lethal to spores of two different postharvest pathogens within an exposure of $\leq 1 \mathrm{~min}$ did not produce a chemical barrier that prevented those pathogens from entering wounded tissues on tomatoes floating in a scale model flume. Storage decays developed despite chlorine concentrations that were 2.5 to 9 times those needed to completely inactivate a similar spore concentration during a 30 to 45 -s exposure in in vitro tests. In a 150-liter flume, viable spores of G. candidum at initial concentrations of $\log _{10} 3.0$ could not be detected after exposure to chlorine at 20 or 25 $\mathrm{mg} /$ liter $\left(\mathrm{pH} 7.0\right.$ and $\left.24^{\circ} \mathrm{C}\right)$ for $45 \mathrm{~s}$ or longer. In three different in vitro tests where spore suspensions were agitated, spores at $\log _{10} 5.8 / \mathrm{ml}$ were completely inactivated by exposure to chlorine at 20 $\mathrm{mg} /$ liter $\left(\mathrm{pH} 6.0\right.$ and $22^{\circ} \mathrm{C}$ ) within $30 \mathrm{~s}$. These tests included use of thiosulfate to inactivate residual chlorine, which reduces the efficacy of the chlorine treatment (2). In contrast, wounded fruit floating in chlorine at $30 \mathrm{mg} / \mathrm{liter}\left(\mathrm{pH} 7.0\right.$ and $\left.24^{\circ} \mathrm{C}\right)$ for 1 min developed about half as much disease in the 6-day incubation period as did control fruit exposed to inoculum alone. Similarly, in tests with $R$. stolonifer, a second postharvest pathogen of tomato fruit, chlorine concentrations required to kill spores in the 150-liter flume within $45 \mathrm{~s}$ did not protect wounded fruit that floated in either the 150-liter flume for $1 \mathrm{~min}$ or the 4-liter flume for $2 \mathrm{~min}$.

Two fungal pathogens were used as models because a lethal chlorine exposure (concentration $\times$ time) for them is roughly 40 times greater than that for E. carotovora subsp. carotovora, the principal posthar-

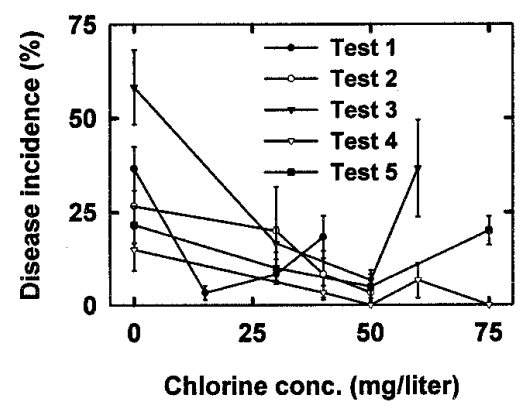

Fig. 3. Disease incidence among tomato fruit that had been wounded four times $(6 \mathrm{~mm}$ deep, $3 \mathrm{~mm}$ wide tapering to $1.5 \mathrm{~mm}$ ) and exposed to chlorinated water and spores of Geotrichum candidum ( $\log _{10} 2.7$ to $3.0 / \mathrm{ml}$ ) for $1 \mathrm{~min}$ in a 150 -liter scale model flume and then stored for 6 days at $24^{\circ} \mathrm{C}$ in five separate tests. Error bars are the standard error of the mean of four separate 15 -fruit samples. 
vest pathogen of tomatoes (14). The small but often variable chlorine demand associated with the water and surfaces of equipment and fruit may confound the results when the test organism is sensitive to less than $1 \mathrm{mg} / \mathrm{liter}$. In typical tests of the sensitivity of gram-negative bacteria to chlorine, the water and equipment are treated to reduce chlorine demand substances prior to tests on the organisms (6).

In repeated tests conducted with beaker and stirring bar, free chlorine at $20 \mathrm{mg} / \mathrm{liter}$ at pH 6.0 was lethal $\left(\log _{10} 5.8\right.$ spore reduction) to spores of G. candidum within 30 to $45 \mathrm{~s}$ of exposure. Robbs et al. (14), using a higher spore concentration, reported that chlorine at $20 \mathrm{mg} / \mathrm{liter}$ at the same $\mathrm{pH}$ produced an approximately $5 \log _{10}$ kill of spores of G. candidum within 2 min. This slight difference in apparent sensitivity may be related to the inactivation of residual chlorine on the samples. Robbs et al. (14) added thiosulfate to the reaction mixture, whereas we added the reaction mixture to thiosulfate-amended medium. Although we compared the two methods for inactivating residual free chlorine and found no major differences in preliminary tests (unpublished data), slower inactivation due to the requirement for diffusion might accompany the addition of thiosulfate to the agar medium. In the 150-liter flume, free chlorine at 20 to $25 \mathrm{mg} / \mathrm{liter}$ at pH 7.0 eliminated detectable spore viability (approximately a $3 \log _{10}$ reduction) within 30 to $45 \mathrm{~s}$. Spores in the flume tests were not treated with thiosulfate and, thus, residual chlorine in the samples may have contributed to the total spore kill. When spores of $R$. stolonifer were added to the flume, somewhat higher chlorine concentrations were required for total inactivation.

In fruit tests conducted in the 150-liter flume, the four separate samples of fruit treated in the same solution were handled as replicates in the calculation of the standard error of the mean. These samples were not classical replicates, where individual treatments are performed randomly. The volume of water and time required for each treatment precluded such an experimental design. If the experimental error inherent in filling the tank with water and adding chlorine to a set ORP is small compared with that associated with different samples of fruit, then fruit samples alone should provide a reasonable estimation of the experimental error. Previously, considerable variation in the latent period for bacterial soft rot was found among fruit that had been wound inoculated with uniform populations of E. carotovora subsp. carotovora and then incubated (1).

The wound size used here was much larger than that common to commercially handled fruit. Culling practices in packinghouses would limit the size of wounds on packed fruit to those made by small objects such as grains of sand, approximately 1.6 $\mathrm{mm}^{3}$ (1). In preliminary tests, fruit with such wounds were not reliably inoculated when exposed to the spore concentrations used (J. A. Bartz and C. G. Eayre, unpublished data). Thus, with proper culling procedures, the decay risk would be minimal in fruit exposed to the spore concentrations used in the 150-liter flume. Proper handling practices that delay disease development (3) also are likely to reduce the need for chlorine concentrations that inactivate fungal spores before they enter potential infection courts on fruit in flumes.

The inability of chlorine concentrations of 50 to $75 \mathrm{mg} /$ liter to prevent viable spores from entering and subsequently infecting wounds on floating tomatoes was confirmed in tests with a 4-liter flume and a 2-min exposure of fruit to chlorine (Fig 3). Chlorine concentrations of up to 180 $\mathrm{mg} / \mathrm{liter}$ failed to protect fruit from inoculation by $R$. stolonifer. Reasons for the apparent discrepancy in chlorine efficacy in tests with spore recovery on agar media versus wounds on fruit are unclear. Free chlorine concentrations should have been maintained at the wound surface by the movement of water in the flume. Major losses in free chlorine due to fruit-associated chlorine demand were not detected. The solution $\mathrm{pH}$ at the wound surface should, if anything, have increased chlorine activity $(6,8,14)$ due to the inherently acidic nature of injured tomato tissues.

The inconsistent control provided by relatively high chlorine concentrations may relate to contact of the wounded tissues with a plume of inoculum. Wounds directly in contact with the plume may have been inoculated before the pathogens were killed by the chlorine. Pathogens in inoculated wounds are relatively insensitive to chlorine $(2,3)$. The attachment of bacteria to glass surfaces as a biofilm produced up to a 150 -fold decrease in sensitivity to chlorine (12) and the attachment of fungal spores to fruit surfaces has been reported (17). However, a biofilm develops because of microbial activity and not simply physical contact $(6,12)$. Either bacterial cells or fungal spores that attach to wound surfaces upon physical contact would have at least one exposed side. The side away from the attachment would have been in contact with moving chlorinated water. The reduction in chlorine sensitivity of an attached microbe should be proportional to the reduction in the exposure. However, if spores entered the intercellular spaces or damaged tissues in wounds, then physical contact with chlorine would be less than anticipated (2,3). In a preliminary examination of wounded tomato fruit under a stereomicroscope, cell sap covered the wound surface (J. A. Bartz and M. Mahovic, unpublished data). Within $15 \mathrm{~s}$ after a watersoluble dye (water blue) had been placed on the wound, blue color framed the walls of cells on the wound surface and appeared to have penetrated into intercellular spaces.
The dye was not completely removed by an immediate washing of the wound with running tap water. If viable spores entered the liquid on wound surfaces, then diffusion in the cell sap or capillary movement of cell sap could carry the spores below the wound surface. Spores lodged in intercellular spaces below the wound surface would be protected from physical contact with chlorine to a degree depending on the depth of penetration. Indeed, washing the surface of dye-treated wounds with $1 \%$ sodium hypochlorite decolored all but a few small spots of water blue dye. Those spots were located well below the wound surface.

An alternative explanation is that the chlorine concentrations used here were fungistatic. Spores were injured but not killed and the injured pathogens recovered better in fruit tissues than on APDA containing thiosulfate. In tests on chlorine toxicity to $G$. candidum or $R$. stolonifer, the development of visible fungal colonies on APDA was delayed by at least $24 \mathrm{~h}$ when spores were treated with chlorine as compared with the water alone control as noted. The recovery of injured microbes is influenced by the environment surrounding the cells (7).

\section{LITERATURE CITED}

1. Bartz, J. A., 1981. Variation in the latent period for bacterial soft rot in tomato fruit. Phytopathology 71:1057-1062.

2. Bartz, J. A. 1999. Washing fresh fruits and vegetables with emphasis on tomatoes and potatoes. Dairy Food Environ. Sanit. 19:853864.

3. Bartz, J. A., and J. W. Eckert. 1987. Bacterial diseases of vegetable crops after harvest. Pages 351-375 in: Postharvest Physiology of Vegetables. J. Weichmann, ed. Marcel Dekker, Inc., New York and Basel.

4. Bender, R. J., Sargent, S. A., Brecht, J. K., and Bartz, J. A. 1992. Effect of tomato grade on incidence of decay during simulated shipping. Proc. Fla. State Hortic. Soc. 105:119121.

5. Brown, G. E., and Wardowski, W. F. 1984. Use of chlorine and chlorine dioxide in Florida citrus packinghouses to reduce inoculum of decay pathogens. Proc. Fla. State Hortic. Soc. 97:97-100.

6. Carlson, S. 1991. Fundamentals of water disinfection. J. Water SRT Aqua 40:346-356.

7. Dodd, C. E. R., Sharman, R. L., Bloomfield, S. F., Booth, I. R., and Stewart, G. S. A. B. 1997. Inimical processes: bacterial selfdestruction and sub-lethal injury. Trends Food Sci. Technol. 8:238-241.

8. Dychdala, G. R. 1977. Chlorine and chlorine compounds. Pages 167-195 in: Disinfection, Sterilization, and Preservation. 2nd ed. S. S. Block, ed. Lea and Febiger, Philadelphia.

9. Ferreira, M. D., Bartz, J. A., Sargent, S. A., and Brecht, J. K. 1996. An assessment of the decay hazard associated with hydrocooling strawberries. Plant Dis. 80:1117-1122.

10. Goepfert, J. M. 1980. Vegetables, fruits, nuts, and their products. Pages 606-642 in: Microbial Ecology of Foods, Vol. II. Food Commodities. J. H. Silliker, R. P. Elliot, A. C. Baird-Parker, F. L. Bryan, J. H. B. Christian, D. S. Clark, J. C. Olson, Jr., and T. A. Roberts, eds. Int. Commission Microbiol. Specifications Foods. Academic Press, New York. 
11. Hicks, J. R., and Segall, R. H. 1974. Water chlorination for vegetable packinghouses. Veg. Crops Fact Sheet VC-1, Fla Coop. Ext. Serv. Univ. Fla. Inst. Food Agric. Sci. Gainesville.

12. LeChevallier, M. W., Cawthon, C. D., and Lee, R. G. 1988. Factors promoting survival of bacteria in chlorinated water supplies. Appl. Environ. Microbiol. 54:649-654.

13. Ogawa, J. M., Hoy, M. W., Manji, B. T., and Hall, D. H. 1980. Proper use of chlorine for postharvest decay control of fresh market tomatoes. Calif. Tomatorama Inf. Bull. No. 27,
Fresh Market Tomato Advis. Board, Bakersfield, CA.

14. Robbs, P. G., Bartz, J. A., Brecht, J. K., and Sargent, S. A. 1995. Oxidation-reduction potential of chlorine solutions and their toxicity to Erwinia carotovora subsp. carotovora and Geotrichum candidum. Plant Dis. 79:158-162.

15. Senter, S. D., Cox, N. A., Bailey, J. S., and Forbus, W. R., Jr. 1985. Microbiological changes in fresh market tomatoes during packing operations. J. Food Sci. 50:254-255.

16. Sherman, M., Showalter, R. K., Bartz, J. A., and Simone, G. W. 1981. Tomato packing- house dump tank sanitation. Veg. Crops Fact Sheet VC-31, Fla. Coop. Ext. Serv. Univ. Fla. Inst. Food Agric. Sci. Gainesville.

17. Spotts, R. A., and Holz, G. 1996. Adhesion and removal of conidia of Botrytis cinerea and Penicillium expansum from grape and plum fruit surfaces. Plant Dis. 80:688-691.

18. Spotts, R. A., and Peters, B. B. 1980. Chlorine and chlorine dioxide for control of d'Anjou pear decay. Plant Dis. 64:1095-1097.

19. White, G. C. 1992. Handbook of Chlorination and Alternative Disinfectants. 3rd ed. Van Nostrand Reinhold, New York. 